\title{
A reduced dose of darunavir/ritonavir is effective in PI-experienced HIV-infected patients
}

\section{Authors}

Massimiliano Lanzafame ${ }^{1}$ Stefano Bonora ${ }^{2}$ Emanuela Lattuada ${ }^{1}$ Andrea Calcagno ${ }^{3}$ Sandro Vento ${ }^{4}$

${ }^{1} \mathrm{MD}$, Infectious Diseases Unit, "G.B. Rossi” Hospital, Verona, Italy

${ }^{2}$ Professor, Department of Infectious Diseases, University of Torino, Torino, Italy ${ }^{3}$ Clinical Researcher; Department of Infectious Diseases, University of Torino, Torino, Italy ${ }^{4}$ Professor; Chief of Department of Internal Medicine, Faculty of Medicine and Health Sciences, University of Botswana, Gaborone, Botswana
Submitted on: 03/22/2011 Approved on: 05/11/2011

Correspondence to: Massimiliano Lanzafame G.B. Rossi Hospital Via piazzale L. Scuro 10 37134, Verona, Italy lanzafame.massimiliano@ gmail.com

We declare no conflict of interest.

(C)2011 Elsevier Editora Ltda. All rights reserved.

\begin{abstract}
Darunavir (DRV) is an HIV-1 protease inhibitor that is used together with a low boosting dose of ritonavir as part of an antiretroviral therapy (ART) regimen in treatment-experienced and naïve HIVpositive patients. In naïve and experienced patients with no DRV-mutations, DRV is licensed at the dose of $800 \mathrm{mg}$ plus $100 \mathrm{mg}$ of ritonavir once daily. We report our results in seven ART-experienced HIV-infected patients, in whom a reduced dose of darunavir/ritonavir (600/100 mg once daily) successfully controlled viral replication
\end{abstract}

Keywords: HIV infections; pharmacokinetics antiretroviral therapy, highly active.

\section{INTRODUCTION}

Darunavir (DRV) is a licensed protease inhibitor with binding characteristics that predict less frequent development of resistance and higher activity against resistant viruses than earlier protease inhibitors. ${ }^{1}$ For treatment-naïve HIV-infected patients, the ARTEMIS trial established the efficacy of the $800 / 100 \mathrm{mg}$ oncedaily dose of darunavir/ritonavir (DRV/r). ${ }^{2}$ In addition, this dose is effective also in treatmentexperienced patients. ${ }^{3-5}$ The once daily dosing is supported by the relatively long terminal elimination plasma half-life of DRV (15 hours). ${ }^{6}$

We report our results in seven antiretroviral therapy (ART)-experienced HIV-infected patients, in whom a reduced dose of DRV/r (600/100 mg once daily) successfully controlled viral replication.

\section{CASE REPORTS}

\section{Patient 1}

A 45-year-old man, HIV-infected from 1992 (CDC C3), who started ART in 1993. After initial zidovudine monotherapy, combination regimens were used (zidovudinedidanosine-nelfinavir for four years, then zidovudine-didanosine-efavirenz for three years) but full virological suppression (HIVRNA $<50$ copies $/ \mathrm{mL}$ ) was reached only in February 2003, when his antiretroviral regimen was changed to stavudine, lamivudine and lopinavir/ritonavir. However, the patient developed severe hypertriglyceridemia $(>1,000 \mathrm{mg} / \mathrm{dL})$ and, despite introduction of fenofibrate and omega 3 fattyacids, normalization of plasma triglycerides was not obtained. In July 2008 (CD4 cells 772/ $\mu \mathrm{L}$, HIV-RNA $<50$ copies $/ \mathrm{mL}$ ) the patient was switched to $\mathrm{DRV} / \mathrm{r} 600 / 100 \mathrm{mg}$ once daily trying to reduce triglyceride plasma levels (still over $500 \mathrm{mg} / \mathrm{dL}$ ). A genotypic resistance test (TRUGENE HIV-1, Bayer Healthcare) performed on PBMC showed resistance mutations for NRTIs, NNRTIs $(41 \mathrm{~L}, 44 \mathrm{D}, 74 \mathrm{~V}$, 101Q, 103H, 108I, 118I, 181C, 184V, 190A, 210W, 215Y, 219R) and PIs (10I, 20M, 36I, $46 \mathrm{I}, 58 \mathrm{E}, 63 \mathrm{~T}, 84 \mathrm{~V}, 90 \mathrm{M}$ ) with one DRV resistance mutation according to the International AIDS Society USA panel resistance testing. ${ }^{7}$

One month after the switch CD4 cells were $768 / \mu \mathrm{L}$ and viral load was undetectable. In January 2009 CD4 lymphocytes rose to $869 / \mu \mathrm{L}$, HIV-RNA continued to be undetectable, and triglyceride level dropped to $334 \mathrm{mg} / \mathrm{dL}$ on fenofibrate only. In March 2009 trough concentration of DRV (determined through a validated high performance liquid chromatography method) $)^{8}$ was $3442 \mathrm{ng} / \mathrm{mL}$. In June 2009 CD4 cells were $834 / \mu \mathrm{L}$, HIV-RNA $<50$ copies $/ \mathrm{mL}$ and plasma triglycerides $224 \mathrm{mg} / \mathrm{dL}$. Fifteen months later (September 2010) CD4 cell count was $940 / \mu \mathrm{L}$ and HIV-RNA $<50$ copies/mL. 


\section{Patient 2}

A 42-year-old man, HIV stage (CDC B3), treated with zidovudine from 1993. He changed many times his antiretroviral regimens (due to only partial adherence, side effects and/or virological failure) until February 2006, when he decided to stop therapy. In January 2007 he came back to our attention because of weight loss and weakness. His CD4 cell count was $23 / \mu \mathrm{L}$ and HIV-RNA level was 41,312 copies $/ \mathrm{mL}$. We restarted therapy using tenofovir/emtricitabine. In July 2007 unboosted fosamprenavir (1,400 mg twice daily) was added, but the patient was again non compliant. In October $2007 \mathrm{CD} 4$ cells rose to $56 / \mu \mathrm{L}$ and HIV-RNA went down to 13,831 copies/mL. In June $2008 \mathrm{CD} 4$ cells were $32 / \mu \mathrm{L}$ and HIV-RNA was 33,250 copies $/ \mathrm{mL}$.

Following a negative HLA-B ${ }^{\star} 5701$ genetic screening and a genotypic resistance test that showed resistance mutations for NRTIs, NNRTIs $(67 \mathrm{~N}, 184 \mathrm{~V}, 190 \mathrm{~A}, 208 \mathrm{Y}, 215 \mathrm{Y})$ and PIs (10I, 13V, 15V, 31I, 46I, 47V, 63P, 77I) with one DRV resistance mutation, ${ }^{7}$ in September 2008 he was started on abacavir/lamivudine and DRV/r 600/100 mg once daily and 3 months later the viral load became undetectable and CD4 cells were $76 / \mu \mathrm{L}$. In March 2009 trough concentration of DRV was 2,143 ng/mL, and in May 2009 viral load was still undetectable and CD4 cells were 209/ $\mu$ L. In October 2009 his CD 4 cell count was $231 / \mu \mathrm{L}$ and HIV-RNA $<50$ copies $/ \mathrm{mL}$. In October 2010 the CD 4 cell count rose to $468 / \mu \mathrm{L}$ with undetectable HIV-RNA.

\section{Patient 3}

A 47-year-old woman with HIV-1 infection (CDC B2) known from 1987, who started antiretroviral therapy in 1995 with zidovudine. Her antiretroviral treatment history was characterized by multiple virological failures (related to a partial adherence to ART) and different antiretroviral drug combinations used. In September 2008 a genotypic resistance test was performed while she was on zidovudine/lamivudine plus tenovofir, with a CD 4 cell count of $271 / \mu \mathrm{L}$ and a viral load of 15,226 copies/mL. The test showed resistance mutations for NRTIs (41L, 184V, 210W, 214F, 215Y) and PIs (10I, 63P, 71T, 73T, 84wt/V, 90M, 93L). To favor adherence she was switched to tenofovir/emtricitabine plus DRV/r 600/100 mg once daily. After 24 months (October 2010) the patient was still aviremic (HIV-RNA $<50$ copies $/ \mathrm{mL}$ ) and CD 4 cells were $428 / \mu \mathrm{L}$. Trough concentration of DRV, evaluated in February 2010, was 4,518 ng/mL.

\section{Patient 4}

A 46-year-old woman with HIV-1 infection (CDC A2), started ART (stavudine, lamivudine and indinavir) in 1997. After three years she was switched to stavudine, didanosine and efavirenz for virological failure. She continued this regimen for eight years without ever obtaining a complete suppression of plasma viral load, which was anyway below
1,000 copies/mL and did not allow for antiretroviral genotyping resistance tests to be performed. In May 2008, the antiretroviral regimen was modified for lipodistrophy and tenofovir/emtricitabine plus fosamprenavir/ritonavir were started. One month later the viral load was undetectable and CD4 cells were $433 / \mu \mathrm{L}$. In September 2008, the viral load was 123 copies/mL. In February 2009, the viral load was 512 copies/mL. In June 2009,(HIV-RNA 586 copies/mL) a genotypic resistance test gave the following results: resistance mutations for NRTIs and NNRTIs $67 \mathrm{~N}, 69 \mathrm{D}, 74 \mathrm{~V}$, $100 \mathrm{I}, 103 \mathrm{~N}, 118 \mathrm{I}, 184 \mathrm{~V}, 210 \mathrm{~W}, 215 \mathrm{Y}, 221 \mathrm{Y}$, and resistance mutations for PIs 10I, 13V, 41K, 46L, 64V, 82F, 93L. In July 2009, a new antiretroviral regimen was started and, to favor adherence, raltegravir (800 mg once daily) and DRV/r (600 mg plus $100 \mathrm{mg}$ of ritonavir once daily) were introduced. After one month HIV-RNA was $<50$ copies/mL and the CD4 cell count rose to 557/ $\mu \mathrm{L}$. In November 2010 (16 months after beginning this regimen, the viral load was still undetectable with a CD4 cell count of $651 / \mu \mathrm{L}$ ); TDM for DRV gave a trough concentration of $844 \mathrm{ng} / \mathrm{mL}$ in February 2010.

\section{Patient 5}

A 44-year-old woman, HIV-1 infection (CDC A2), started her first antiretroviral regimen in 1996. After various regimens the last genotypic resistance test gave the following results, while she was on emtricitabine/tenofovir, atazanavir/ritonavir and HIV-RNA level was 8,450 copies/mL: resistance mutations for NRTIs and NNRTIs $41 \mathrm{~L}, 74 \mathrm{~V}, 184 \mathrm{~V}$, 210W, 215Y, and resistance mutations for PIs 10F, 35G, 43T, 50L, 71V, 73S, 74S, 90M.

In March 2010, the patient started emtricitabine/tenfovir plus DRV/r (600/100 mg once daily), and in September 2010 her viral load was $<50$ copies/mL with a CD4 cell count of $882 / \mu \mathrm{L}$.

\section{Patient 6}

A 41-year-old man, HIV-1 infection (CDC C3), started on ART in 2003 (zidovudine/lamivudine and lopinavir/ritonavir). After two months the regimen was switched to didanosine, zidovudine and nevirapine for gastrointestinal side effects related to lopinavir/ritonavir. In August 2004, this regimen failed (HIV-RNA 17,546 copies/mL). The patient defaulted and returned to our attention after 9 months, with a CD4 cell count of 296/ $\mu \mathrm{L}$ and HIV-RNA 44,549 copies $/ \mathrm{mL}$. We decided to start a new antiretroviral regimen consisting of didanosine, lamivudine and atazanavir/ritonavir. In December 2005, the CD4 cell count was 509/ $\mu \mathrm{L}$ with undetectable HIV-RNA. In March 2009, HIV-RNA rose to 1,158 copies $/ \mathrm{mL}$ with a CD4 cell count of $546 / \mu \mathrm{L}$. A genotypic resistance test showed the following resistance mutations: $215 \mathrm{~N}$ and 33F, 34Q, 36V, 50L, 63P, 71V, 77I, 82A, 93L. The patient defaulted again and 10 months later came back to our attention with a relapse of PCP. His CD4 cell 
count was $83 / \mu \mathrm{L}$ and HIV-RNA was 111,426 copies/mL. Emtricitabine/tenofovir and lopinavir/ritonavir were started. At the end of February 2010, with persistent gastrointestinal side effects, the patient was switched from lopinavir/ $\mathrm{r}$ to darunavir/r (600/100 mg once daily). In October 2010, the CD4 cell count had raised to $216 / \mu \mathrm{L}$ and HIV-RNA was undetectable.

\section{Patient 7}

A 44-year-old woman, HIV-1 infection (CDC C3), multidrug experienced. After the last failure in 2004, a genotypic resistance test was performed (resistance mutations $67 \mathrm{~N}$, 70R, 100I, 103N, 215Y, 219E and 10I, 63P, 82A). She was put on lamivudine, abacavir and lopinavir/ritonavir. In September 2010, she refused to continue her antiretroviral regimen for long-term side effects (alopecia and lypodistrophy). We began DRV/r (600/100 mg once daily) monotherapy and four months later the patient was aviremic.

\section{DISCUSSION}

Darunavir binds with very high affinity to HIV-1 protease and fits closely within the substrate envelope, two factors associated with its potency and high genetic barrier. ${ }^{8}$ DRV plus a low boosting dose of ritonavir is approved for use in treatment-experienced adults with HIV-1 infection, and for use in treatment-naive adults at the dosage of $800 / 100 \mathrm{mg}$ once-daily. ${ }^{9}$ Some evidence indicates that this dose can be used also for a few treatment-experienced patients. ${ }^{3-5}$ Our results show that a lower DRV/r dose $(600 / 100 \mathrm{mg}$ once daily) can be used safely and successfully in highly experienced patients.

Indeed pharmacokinetic analysis available for four patients, trough concentration values above the protein-binding-corrected DRV IC50 for protease inhibitor-resistant viruses $(550 \mathrm{ng} / \mathrm{mL}) .{ }^{10}$ Genotypic resistance tests showed that this regimen was effective even in the presence of one major DRV-associated mutation.

Recently it has been showed that among different resistance interpretation algorithms and derived gIQs, gIQ WS was the most accurate predictive model for achieving a successful virological response. ${ }^{11}$ In all of our four patients with pharmacokinetic analysis gIQ WS was always $\geq 600$ and predictable of 48 weeks virological response.

On the basis of our experience, we think that a $600 / 100 \mathrm{mg}$ once daily $\mathrm{DRV} / \mathrm{r}$ dose could be tested in large, well powered efficacy trials, in comparison with the recognized standard of care.

\section{REFERENCES}

1. Deschamps D, Lambert-Niclot S, Marcelin AG et al. Mutation associated with virological response to darunavir/ritonavir in HIV-1-infected protease inhibitor-experienced patients. J Antimicrob Chemother 2009; 63:585-92.

2. Ortiz R, DeJesus E, Khanlou $\mathrm{H}$ et al. Efficacy and safety of once-daily darunavir/ritonavir versus lopinavir/ritonavir in treatment-naïve HIV-1-infected patients at week 48. AIDS 2008; 22:1389-97.

3. Arasteh K, Clumeck N, Pozniak A et al. TMC 1147 ritonavir substitution for protease inhibitor(s) in a non-suppressive antiretroviral regimen: A 14-day-proof-of-principle trial. AIDS 2005; 19:943-7.

4. De Meyer S, Spinoza-Guzman S, Vangeneugden T et al. Efficacy of once-daily darunavir/ritonavir $800 / 100 \mathrm{mg}$ in HIVinfected, treatment-experienced patients with no resistanceassociated mutations to darunavir. J Acquir Immune Defic Syndr 2008; 49:179-82.

5. Cahn P, Fourie J, Grinsztejn B et al. Efficacy and safety of 48 weeks of once-daily vs twice daily DRV/r in treatment-experienced HIV-1+ patients with no DRV resistance-associated mutations:the ODIN trial 17th Conference on Retroviruses and Opportunistic Infections, San Francisco, California, February 2010 [ abstr 57].

6. Boffito M, Miralles D, Hill A. Pharmacokinetics, efficacy, and safety of darunavir/ritonavir $800 / 100 \mathrm{mg}$ once-daily in treatment-naïve and -exeprienced patients. HIV Clin Trials 2008; 9:418-27.

7. Johnson VA, Brun-Vezinet F, Clotet B et al. Update of the drug resistance mutations in HIV-1: Spring 2008. Top HIV Med $2008 ; 16: 62-8$.

8. Dierynck I, De Wit M, Gustin E et al. Binding kinetics of darunavir to human immunodeficiency virus type 1 protease explain the potent antiviral activity and high genetic barrier. J Virol 2007; 81:13845-51.

9. McKeage K, Perry CM, Keam SJ. Darunavir: a review of its use in the management of HIV infection in Adults. Drugs 2009; 69:477-503.

10. De Meyer S, Azijn H, Surleraux D et al. TMC 114, a novel human immunedeficiency virus type 1 protease inhbitor active against protease inhibitor-resistance viruses, including a broad range of clinical isolates. Antimicrob Agents Chemother 2005; 49:2314-21.

11. Gonzalez de Requena D, Bonora S, Vigano O et al. Comparative evaluation of seven resistance interpretation algorithms and their derived genotypic inhibitory quotients for the prediction of 48-week virological response to darunavir-based salvage regimens. J Antimicrob Chemother 2011; 66:192-200. 